\title{
Studi Literatur tentang Kerjasama Ventura Internasional sebagai Salah Satu Model Entri dalam Strategi Internasional ${ }^{*}$
}

\author{
Ferdi Nazirun Sijabat ${ }^{1,2}$ dan Nurdasila Darsono ${ }^{1}$ \\ ${ }^{1}$ Fakultas Ekonomi dan Bisnis, Universitas Syiah Kuala \\ ${ }^{2}$ Sekolah Tinggi Ilmu Ekonomi Sabang
}

\begin{abstract}
Abstrak
Artikel ini bertujuan mereview faktor-faktor apa saja yang menjadi penentu kinerja perusahaan kerjasama ventura internasional berdasarkan penelitian yang dilakukan oleh peneliti sebelumnya. Artikel ini mereview sebanyak 35 artikel dari berbagai jurnal bereputasi dalam bidang kajian strategi internasional yang terdiri dari : model entri ( 9 artikel), kerjasama ventura internasional (10 artikel), dan artikel yang terkait dengan strategi internasional (15 artikel) selebihnya adalah sumber non-artikel seperti buku dan kertas kerja. Pada bagian akhir, artikel ini juga memaparkan sejumlah rekomendasi bagi penelitian selanjutnya.
\end{abstract}

Key words: strategi internasional, model entry, kerjasama ventura internasional

\section{Pendahuluan}

Studi tentang internasional strategi kian mendapatkan perhatian di kalangan para peneliti baik dalam lingkup perusahaan multinasional maupun perusahaan kecil dan menengah, bahkan ada yang membangun satu bidang kajian yang fokus pada ventura baru internasional (Oviatt \& McDougal, 1994), kewirausahaan internasional (Wach, 2013) dan menjadikan teori yang ada sebagai basis untuk mengembangkan teori berbasis kepercayaan China kuno, yin dan yang (Fung, 2014). Untuk masing-masing studi tersebut, para peneliti memunculkan berbagai perspektif sesuai dengan kecenderungan masing-masing.

Kajian bisnis internasional pun tidak lagi dipandang sebagai fenoman baru apalagi jika dilihat dari volume perdagangan di era globalisasi terus mengalami peningkatan (Katavic, n.d.). Tujuan utama perusahaan untuk beroperasi di pasar internasional terlepas dari besar dan kecilnya skala perusahaan, tidak dapat dilepaskan dari motivasii mengejar keuntungan (Ruzzier et al., 2016, Katavic, n.d), keterbatasan pasar dalam negeri (Katavic, n.d.), pertumbuhan dan ekspansi (Twarowska \& Kakol, 2013).

Untuk kajian internasionalisasi usaha multinasional misalnya ada yang menggunakan metode foreign direct investment, born global dan networking. Perspektif lainnya yang 
juga mendapat banyak sorotan dari kalangan peneliti adalah tentang lingkungan bisnis internasional (Ferreira, Li, Guisinger \& Seraa, 2009), international alliance (Twarowska \& Kakol, 2013), entry mode dan jarak institusional (institusional distance) (loanescu, Meyer \& Estrin, 2004) yang bermula dari penelitian tentang physical distance yang dipelopori Andersson, Johansson \& Vahlne (1997) dan dilanjutkan dengan pengembangan indeksnya oleh Kogut dan Singh (1998).

Dalam hal institusional distance, lonascu, Myer \& Estrin (2004) merupakan salah satu variasi dalam penelitian tentang strategi internasional. Adapun prinsip dasar dalam kajian institusional distance ini adalah perlu melakukan penyesuaian terhadap aspek budaya, peraturan, kognitif, sehingga dengan dasar itu kemudian dapat ditentukan strategi, bentuk organisasi dan prosedur internal. Sebab semakin jauh jarak antara perusahaan dengan negara tujuan investasi semakin banyak perbedaan prinsipil. Namun Henisz (2003) mencatat bahwa kekhawatiran akan distance ini umumnya dialami perusahaan multinasional dari negera Barat. Di mana perbedaan yang ada di negara tujuan investasi bisa berdampak terhalangnya mereka masuk ke negara tersebut. Hal ini menjadi pembeda bagi perusahaan multinasional yang berasal dari kawasan Asia.

Demikian halnya peneliti yang memfokuskan pada internasionalisasi usaha kecil dan menengah menggunakan beberapa pendekatan yang populer seperti model upsala (stages model), inovasi, networking dan pre-internasionalisation (Ruzzier, Hirsich \& Antoncic, 2006; Sijabat, 2018), aspek sumber daya manusia (katarcic, n.d.), dan international new venture (ventura baru internasional) (Nowinski \& Rialph, 2013).

Pada bagian lain, Tallman (2014) memberi perbedaan yang jelas antara domain yang termasuk dalam kajian strategi internasional dan yang tidak. Kajian tentang satu perusahaan multinasional yang beroperasi di negara tertentu tidak dapat dikategorikan sebagai kajian strategi internasional, jika tidak memberikan implikasi apapun terkait dengan internasionalisasi.

Pada tataran empiris, Huo dan Hung menemukan bahwa strategi internasionalisasi berhubungan positif dengan kinerja organisasi, dan secara tidak langsung juga berhubungan dengan dengan kinerja organisasi melalui leverage keuangan. Studi ini dlakukan dalam konteks perusahaan IT di China.

\section{Strategi Internasional}

Twarowska \& Kakol (2013) mendefinisikan strategi internasional sebagai kegiatan yang dilakukan oleh anak perusahaan secara independen yang keberadaannya terpencar secara internasional (di berbagai negara) melakukan kegiatan operasional perusahaan seperti halnya perusahaan lokal di tempat mereka berada. Twarowska \& Kakol (2013) membedakan antara strategi internasional dan strategi global dalam tiga hal. 1. Level 
koordinasi. strategi Internasional tidak mempersyaratkan adanya koordinasi yang kuat dari perusahaan induk terhadap anak perusahaan, sebaliknya, strategi global mempersyaratkan adanya koordinasi yang kuat atas anak perusahaan; 2. Strategi internasional tidak begitu tegas dalam hal standardisasi produk di negara tujuan, perlu dilakukan jika memang ada tuntutan demikian. Sebaliknya dalam strategi global, produ yang didistribusikan di negara manapun harus sesuai standar perusahaan induk, kecuali ada faktor yang menghendaki kebalikannya; dan 3. Dalam hal persaingan, strategi internasional, perusahaan induk memberikan kebebasan kepada anak perusahaan untuk menentukan langkah persaingan yang ingin dilakukan. Sedangkan dalam strategi global, langkah persaingan diatur berskala global, di mana perlakuan terhadap persaingan bersifat terintegrasi antara perusahana induk dan perusahaan anak.

Meskipun demikian penggunaan istilah global strategi dan internasional strategi masih juga digunakan dalam makna yang sama. Misalnya Muciimi dan Ngumo (2014) merangkum sejumlah strategi yang terkait dengan strategi global atau internasional, yaitu: teori berbasis organisasi industrial dan teori berbasis sumber daya.

Artikel ini bertujuan untuk melakukan studi literatur berbentuk naratif (narrative artikel review) tentang salah satu model entry dalam strategi internasional yaitu kerjasama ventura internasional (international joint venture) dengan meriview sebanyak 36 artikel terinci dalam Tabel 1-- yang terdiri dari model entri (9 artikel), kerjasama ventura internasional (11 artikel), dan lainnya yang terkait dengan strategi internasional (16 artikel). Artikel tersebut bersumber dari jurnal-jurnal bereputasi dalam bidang strategi bisnis internasional seperti Journal of International Business Studies, Strategic Management Journal, Journal of Management, Academy of Management Journal, Journal of Management, Journal of World Business, Journal of Business Venture dan beberapa jurnal lainnya. Pencarian artikel dilakukan melalui mesin pencari google dan lebih spesifik pada database Google Scholar dengan perpaduan beberapa kata kunci seperti "international strategy", "international business strategy", "entry mode strategy", "international joint venture", dan "international joint venture performance". Selanjutnya artikel ini akan membahas tentang teori dan strategi model entri, kemudian membahas tentang teori biaya transaksi sebagai lensa teori kerjasama ventura internasional dan kritik terhadap teori tersebut serta review terhadap penelitian empiris tentang kerjasama ventura internasional. Artikel ini ditutup dengan kesimpulan dan rekomendasi arah penelitian berikutnya. 
Tabel 1 Matriks artikel yang direview

\begin{tabular}{|c|c|c|c|}
\hline Jurnal & $\begin{array}{l}\text { Jumlah } \\
\text { Aritkel }\end{array}$ & Penulis & Fokus \\
\hline $\begin{array}{l}\text { Academy of } \\
\text { Mangement } \\
\text { Journal }\end{array}$ & 2 & $\begin{array}{l}\text { Gulati (1995); } \\
\text { Geysken (2006) }\end{array}$ & $\begin{array}{l}\text { 1. Pemilihan aliansi kontraktual } \\
\text { berdasarkan hubungan yang berulang } \\
\text { 2. Teori Biaya Transaksi dan kaitannya } \\
\text { dengan aliansi bisnis }\end{array}$ \\
\hline $\begin{array}{l}\text { Journal of } \\
\text { International } \\
\text { Business Studies }\end{array}$ & 8 & $\begin{array}{l}\text { Pan \& Tse (1996); } \\
\text { Kogut \& Singh } \\
\text { (1988);Agarwal \& } \\
\text { Ramaswami } \\
\text { (1992); Kim \& } \\
\text { Hwang (1992); } \\
\text { Oviatt \& McDougal } \\
\text { (1994); Buckley \& } \\
\text { Casson (1998); } \\
\text { Zhao, Luo, \& Suh } \\
\text { (2004); } \\
\text { Brouthers (2013); }\end{array}$ & $\begin{array}{l}\text { 1. Kerjasama antara perusahaan asing di } \\
\text { pasar luar negeri; } \\
\text { 2. Pengaruh budaya nasional terhadap } \\
\text { model entry; } \\
\text { 3. Pengaruh Kepemilikan, Lokasi, \& } \\
\text { Internasionalisasi dalam pemilihan model } \\
\text { entry; } \\
\text { 4. Strategi global dan pilihan model entry; } \\
\text { 5. Determinan Biaya Transaksi dan } \\
\text { pemilihan model entry berdasarkan } \\
\text { kepemilikan; Strategi model entry dengan } \\
\text { pendekatan internasional yang diperluas; } \\
\text { pengaruh teori institusional,budaya, dan } \\
\text { transaksi terhadap kinerja \& pemilihan } \\
\text { model entry }\end{array}$ \\
\hline $\begin{array}{l}\text { Journal of World } \\
\text { Business }\end{array}$ & 3 & $\begin{array}{l}\text { Kumar \& } \\
\text { Subramaniam } \\
\text { (1997); Ainuddin, } \\
\text { Beamish, Hulland } \\
\text { \& Rouse (2007); } \\
\text { Hitt, Li \& Xu } \\
\text { (2016) }\end{array}$ & $\begin{array}{l}\text { 1. Keputusan model entry } \\
\text { 2. Pengaruh Sumber Daya terhadap Kinerja } \\
\text { Perusahaan Ventura Internasional; } \\
\text { 3. Strategi internasional dari lokal ke global }\end{array}$ \\
\hline $\begin{array}{l}\text { International } \\
\text { Studies of } \\
\text { Management and } \\
\text { Organisation }\end{array}$ & 1 & $\begin{array}{l}\text { Baird, Lyles \& } \\
\text { Wharton (1990) }\end{array}$ & $\begin{array}{l}\text { Kesuksesan kerjasama ventura internasional AS- } \\
\text { China }\end{array}$ \\
\hline $\begin{array}{l}\text { Problem and } \\
\text { Perspective in } \\
\text { Management }\end{array}$ & 1 & $\begin{array}{l}\text { Ahmad \& Kitchen } \\
\text { (2008) }\end{array}$ & $\begin{array}{l}\text { Motivasi dan pemilihan model entry perusahaan } \\
\text { konstruksi }\end{array}$ \\
\hline $\begin{array}{l}\text { Journal of } \\
\text { Management }\end{array}$ & 2 & $\begin{array}{l}\text { Brouthers \& } \\
\text { Hennart (2007); } \\
\text { Ren, Gray, \& Kim } \\
(2009)\end{array}$ & $\begin{array}{l}\text { 1. Pemahaman tentang model entry; } \\
\text { 2. Faktor-Faktor yang membuat perbedaan } \\
\text { dalam kinerja perusahaan ventura } \\
\text { internasional }\end{array}$ \\
\hline $\begin{array}{l}\text { Strategic } \\
\text { Management } \\
\text { Journal }\end{array}$ & 4 & $\begin{array}{l}\text { Hill \& Kim (1988); } \\
\text { Hennart (1988); } \\
\text { Kogut } \\
\text { (1998);Chang \& } \\
\text { Rosenzweig } \\
\text { (2001); }\end{array}$ & $\begin{array}{l}\text { 1. Studi tentang Teori Biaya Transaksi; } \\
\text { 2. Teori Biaya transaksi pada kerjasama } \\
\text { ventura internasional; Pendekatan teoritis } \\
\text { dan emprisi kerjasama ventura } \\
\text { internasional; } \\
\text { 3. Pemilihan model entry berdasarkan } \\
\text { urutan penanaman modal asing (FDI) }\end{array}$ \\
\hline $\begin{array}{l}\text { Journal of } \\
\text { Strategy and } \\
\text { Management }\end{array}$ & 1 & $\begin{array}{l}\text { Bener \& Gleister } \\
(2010)\end{array}$ & $\begin{array}{l}\text { Determinan kinerja perusahaan ventura } \\
\text { internasional }\end{array}$ \\
\hline $\begin{array}{l}\text { Journal of } \\
\text { International } \\
\text { Marketing }\end{array}$ & 1 & $\begin{array}{l}\text { Covielo \& Martin } \\
\text { (1999) }\end{array}$ & Internasionalisasi Usaha Kecil dan Menengah \\
\hline
\end{tabular}




\begin{tabular}{|c|c|c|c|}
\hline $\begin{array}{l}\text { International } \\
\text { Business Review }\end{array}$ & 1 & $\begin{array}{l}\text { Devilla et al. } \\
(2014)\end{array}$ & $\begin{array}{l}\text { Model entry dalam dunia yang multikutub dengan } \\
\text { mediasi lingkungan politik }\end{array}$ \\
\hline $\begin{array}{l}\text { Organization } \\
\text { Science }\end{array}$ & 1 & $\begin{array}{l}\text { Hans \& Tallman } \\
\text { (1997) }\end{array}$ & Pengendalian dan Kinerja Ventura Internasional \\
\hline $\begin{array}{l}\text { Australasian } \\
\text { Marketing } \\
\text { Journal }\end{array}$ & 1 & $\begin{array}{l}\text { Hersch \& Styles } \\
(2001)\end{array}$ & $\begin{array}{l}\text { Kerjasama ventura internasional dengan } \\
\text { kerangka ekonomi politik }\end{array}$ \\
\hline $\begin{array}{l}\text { Journal of } \\
\text { Innovation and } \\
\text { Knowledge }\end{array}$ & 1 & Lin \& Ho (2019) & $\begin{array}{l}\text { Pengetahuan model entry bagi usaha kecil dan } \\
\text { menengah }\end{array}$ \\
\hline $\begin{array}{l}\text { Journal for East } \\
\text { European } \\
\text { Management } \\
\text { Studies }\end{array}$ & 1 & $\begin{array}{l}\text { Nowinski \& Ralp } \\
\text { (2013) }\end{array}$ & $\begin{array}{l}\text { Strategi dan faktor pendorong ventura baru } \\
\text { internasional }\end{array}$ \\
\hline $\begin{array}{l}\text { Journal of Small } \\
\text { Business and } \\
\text { Enterprise } \\
\text { Development }\end{array}$ & 1 & $\begin{array}{l}\text { Ruzzier, Hisrich \& } \\
\text { Antoncic (2006) }\end{array}$ & Internasionalisasi Usaha Kecil dan Menengah \\
\hline $\begin{array}{l}\text { Asia Pacific } \\
\text { Business Revie }\end{array}$ & 1 & $\begin{array}{l}\text { Thuy \& Quang } \\
\text { (2005) }\end{array}$ & $\begin{array}{l}\text { Modal relasional dan kinerja perusahaan } \\
\text { kerjasama ventura internasional }\end{array}$ \\
\hline $\begin{array}{l}\text { Management } \\
\text { International } \\
\text { Review }\end{array}$ & 1 & $\begin{array}{l}\text { Andersson, } \\
\text { Johanson \& } \\
\text { Vahlne (1997) }\end{array}$ & Proses internasionalisasi bisnis perusahaan \\
\hline $\begin{array}{l}\text { Journal of } \\
\text { Business } \\
\text { Venturing }\end{array}$ & 1 & $\begin{array}{l}\text { Lu \& Beamish } \\
(2006)\end{array}$ & $\begin{array}{l}\text { Strategi dan Kinerja ventura internasional dalam } \\
\text { konteks perusahaan UKM }\end{array}$ \\
\hline $\begin{array}{l}\text { The Chinese } \\
\text { Economy }\end{array}$ & 1 & Fung (2014) & Pengembangan teori yin dan yang \\
\hline $\begin{array}{l}\text { International } \\
\text { Journal of } \\
\text { Science and } \\
\text { Research }\end{array}$ & 1 & $\begin{array}{l}\text { Muciimi \& Ngumo } \\
\text { (2014). }\end{array}$ & $\begin{array}{l}\text { Pendekatan multisektoral strategi bisnis } \\
\text { internasional }\end{array}$ \\
\hline
\end{tabular}

\section{Teori dan strategi yang melandasi pemilihan model entri}

Devilla et al (2014) mengidentifikasi ada enam mazhab atau teori yang dapat digunakan untuk memilih keempat entry mode itu. Adapun keenam mazhab tersebut ialah: Uppsala model, biaya transaksi, real options, paradigma ekeletik, jaringan industrial, dan pendekatan institusional.

Hampir senada dengan Devilla et al. (2014), Brouthers \& Hennart (2007) menyebutkan teori yang melandasi pemilihan entri mode adalah : biaya transaksi, resource based view, toeri institusional, kerangka ekletik. Dalam hal ini, Brouthers \& Hennart (2007) tidak memasukkan teori uppsala, industrial network dan real options sebagai teori dalam pemilihan entry mode. Keduanya tidak menjelaskan kenapa ada tiga pendekatan yang tidak dipilih sebagai teori, padahal teori upsala sudah lebih dulu ada pada tahun 1970-an. Namun brouthers baru memasukkan teori real option dalam kajiannya pada tahun 2008 (Brouthers \& Brouthers, 2008). 
Pendekatan lainnya yang juga digunakan dalam penelitian tentang entry mode adalah institutional distance. Pendekatan ini menjadikan jarak antara perusahaan induk ke negara tujuan investasi sebagai pertimbangan dalam membuat keputusan. Pendekatan ini antara lain dilakukan oleh loanescu et al. (2004) yang menguji pengaruh jarak institusional dalam konteks normatif, regulatoris dan kognitif terhadap strategi masuk ke pasar emerging countries. loanescu et al. (2004) menggunakan tiga indeks untuk mengukur jarak dari bisnis internasional yaitu Kogut-Sighn index, regulasi, dan jarak kognitif.menggunakan metode data set banyak perusahaan induk di banyak lokasi investasi tujuan (multi-host multi-home), yang dapat digunakan untuk mengukur pengaruh dari jarak antara perusahaan induk dengan lokasi anak perusahaan.

Perdebatan tentang landasan teoritis yang digunakan dalam meneliti model entry dalam konteks strategi internasional sepertinya tidak akan berakhir, Selain beberapa teori di atas, jika ditinjau lebih spesik penelitian tentang kinerja perusahaan kerjasama ventura internasional juga masih belum ada keseragaman teori (Robson et al., 2002). Beberapa teori yang digunakan antara lain : 1. Biaya transaksi; 2. Pendekatan internasionalisasi; 3. Pendekatan strategi bersaing; 4. Pendekatan pembelajaran dan pengetahuan organisasi; dan 5. Pendekatan ketergantungan sumberdaya (Demirbag \& Mirza, 2000). Sedangkan Robson et al. (2002) menggunakan teori biaya transaksi, teori agensi, resource-base view, perspektif perilaku, pembelajaran/pengetahuan organisasi, ekonomi politik, dan manajemen strategis. Dari dua pandangan tersebut, ada dua teori yang sama-sama digunakan yang itu biaya transaksi dan pembelajaran/pengetahuan organisasi. Demirbag \& Mirza (2000) berhasil mengidentifikasi teori yang melatarbelakangi pembentukan kerjasama ventura internasional, yang belum diakomodasi oleh penelitian sebelumnya.

Tabel 2. Teori Model Entri

\begin{tabular}{|c|c|}
\hline $\begin{array}{c}\text { Teori } \\
\text { Entri Mode }\end{array}$ & Peneliti \\
\hline Uppsala Model & \multirow{12}{*}{$\begin{array}{l}\text { Devilla et all (2014), Brouthers \& } \\
\text { Brouthers (2008), Brouthers \& } \\
\text { Hennart (2007), Ainuddin et al } \\
\text { (2007)dan loanescu et al. (2004), } \\
\text { Demirbag \& Mirza (2000); } \\
\text { Johanson \& Vahlne (1977); }\end{array}$} \\
\hline Biaya Transaksi & \\
\hline Real Option & \\
\hline Paradigma Eklektik & \\
\hline Jaringan Industrial & \\
\hline Pendekatan Institusional & \\
\hline Resource Base View & \\
\hline Internasionalisasi & \\
\hline Pendekatan Persaingan & \\
\hline Pembelajaran Organisasi & \\
\hline Sumber Daya Manusia & \\
\hline Institutional Distance & \\
\hline
\end{tabular}


Studi strategi internasional dalam konteks model entri dimulai sejak tahun 1972 berdasarkan artikel yang pertama sekali ditulis dalam bidang tersebut (seminal paper) oleh Stopford dan Welss, meskipun dalam artikel tersebut kedua peneliti itu belum memberikan penjelasan yang detil tentang entry mode (Brouthers \& Hennart, 2007). Dengan demikian penelitian tentang entry sudah berlangsung selama 48 tahun.

Pemilihan entry mode merupakan salah satu strategi yang penting bagi perusahaan yang ingin masuk ke pasar luar negeri (Agarwal \& Ramaswami, 1992; Root, 1994; Brouthers, 2013; Hitt, Li \& Xu, 2016), karena setiap modenya memberikan manfaat dan resiko serta perbedaan dalam hal kendali dan faktor biaya (Chang \& Rosenzweig, 2001).

Secara umum diantara pilihan model entri yang tersedia adalah : ekspor, lisensi, join ventura, dan kepemilikan terhadap anak perusahaan (Root, 1994). Keempatnya pilihan entry mode itu diklasifikasikan menjadi dua bagian yang itu berbasis ekuitas seperti kepemilikan penuh terhadap anak perusahaan dan join ventura, dan non-ekuitas yang terdiri dari ekspor dan perjanjian kontrak (lisensi) (Kumar \& Subramaniam, 1997; Pan \& Tse, 2000).

Osland et al. (2001) pada umumnya perusahaan yang melakukan internasionalisasi akan berhadap dengan tantangan, khususnya untuk mengelola strukturnya. menemukan adanya perbedaan antara perusahaan AS dan Jepang ketika membuat pertimbangan untuk memiliki entry mode ke pasar tujuan. Perusahaan Jepang lebih mempertimbangkan pada faktor resiko yang mungkin muncul pada pasar di negara tujuan, sedangkan perusahaan AS lebih mempertimbangkan pengalaman internasional yang dimiliki.

Dari berbagai pilihan entry mode, kerja sama ventura internasional merupakan diantaranya yang paling banyak dipilih. Sebagai contoh di Malaysia pada tahun 2008, berdasarkan studi yang dilakukan Ahmad dan Kithchen terhadap perusahaan jasa konstruksi di Malaysia yang melakukan ekspansi keluar negeri memilih beberapa entry mode yaitu: kerja sama ventura internasional (54,3\%), Aliansi strategis $(31,4 \%)$, contractual agreement $(11,4 \%)$ dan ekspor $(2.9 \%)$. Adapun pemilihan keempat model entry itu didasarkan pada kemudahan untuk mendirikannya dan minim resiko.

\section{Biaya Transaksi Sebagai Lensa Teori Kerjasama Ventura Internasional}

Menurut Nippa dan Reuer (2019) teori ini berakar dari teori ekonomi yang pertama sekali dipopulerkan oleh Hymer pada tahun 1972. Namun jika telusuri lebih jauh ke belakang, teori ini merujuk kepada teori internasional yang pertama kali dikemukakan oleh Ronald Coase pada tahun 1937. Teori ini berpendapat bahwa ada satu kondisi (persyaratan) yaitu biaya transaksi untuk kegiatan investasi di luar negeri yang 
membuat perusahaan jauh lebih efisien jika beroperasi di pasar dalam negeri dibandingkan pasar luar negeri (Hermannsdottir, 2008).

Hermannsdottir (2008) juga menambahkan berdasarkan pendekatan ini, perusahaan multinasional diasumsikan telah mengembangkan keunggulan yang spesifik di pasar domestik. Keunggulan dapat berupa aset yang berwujud, pengetahuan yang membuat suatu perusahaan itu dapat memiliki produksi, produk, pemasaran dan pengetahuan manajemen yang super. Menurut Covielo dan Martin (1999) pemilihan bentuk organisasi dan lokasi perusahaan berdasarkan teori biaya transaksi yang dijadikan pertimbangan adalah bagaimana meminimalisir biaya yang dikeluarkan.

Dalam pandangan teori ini menurut Kogut (1988) aliansi bisnis (antara mitra bisnis) terjadi karena adanya jumlah biaya transaksi dan produksi yang diasosiasikan dengan kerja sama ventura itu jauh lebih rendah dibandingkan kepemilikan tunggal dan transaksi pasar keuangan.

Apa saja faktor yang menghabiskan banyak biaya dalam kegiatan internasionalisasi bisnis adalah : 1. Biaya modal untuk membangun bisnis di luar negeri; 2. Biaya yang berkaitan dengan upaya memperkenalkan perusahaan kepada budaya dan pasar lokal;3. Biaya transfer pengetahuan (know-how) ke luar negeri dengan menggunakan pasar internal; dan 4. Biaya terkait pengendalian terhadap ekspansi organisasi (Hill \& Kim, 1988).

Banyak peneliti yang mengemukakan bahwa teori biaya transaksi dapat digunakan dalam memahami IJV (Seperti Robson et al., 2002; Zhao et al., 2004; Geyskens et al., 2006; Brouthers \& Hennart, 2007, Brouthers \& Brouthers 2008, Buckley \& Casson, 2009; Devillat et al., 2014; Hennart, 1988 \& 2019,). Akan tetapi, para peneliti yang menggunakan teori tersebut memiliki perbedaan pemahaman tentang asumsi dasar dan operasionalisasinya serta pembuktiannya secara empiris juga belum tuntas (Nippa \& Reuer, 2019).

Berbeda dengan peneliti lainnya, Robson et al. (2002) lebih memilih pendekatan yang pluralis dengan menggunakan banyak teori dan konstruk yang ditemukan dari berbagai literatur terkait ventura internasional, kemudian dia mengembangkan satu framework yang terintegrasi.

Sepanjang pengetahuan peneliti, Robson et al. (2002) adalah satu-satunya peneliti berupa menggabungkan seluruh pendekatan teoritis dan konstruk terkait ventura internasional. Peneliti ini berhasil menciptakan satu kerangka kerja yang menyeluruh yang mencakup faktor internal dan eksternal perusahaan kerja sama ventura internasional, domain perusahaan induk, dan domain perusahaan ventura serta kaitannya terhadap kinerja. 
Pendekatan institusional diartikan sebagai penjelasan mengenai pengaruh eksternal terhadap organisasi dan dalam upaya menjelaskan tetang tingkat bentuk homogenitas, perilaku dan praktik untuk guru yang berbeda.

Berdasarkan dua pandangan di atas terlihat bahwa ada beberapa teori yang dijadikan sebagai landasan untuk pengambilan keputusan tentang entri mode yang akan dipilih oleh perusahaan multinasional dan perusahaan usaha kecil menengah yang ingin melakukan ekspansi ke pasar luar negeri. Baik De Villa et al. (2014) dan Brouthers \& Hennart (2007) yaitu teori biaya transaksi, pendekatan ekletik dan pendekatan institusional. Masing-masing peneliti tersebut tidak menyebutkan alasan kenapa Devilla (2014) tidak menyebutkan resource based view sebagai salah satu teori untuk mengidentifikasi entry mode. Demikian juga Brothers \& Hennart (2007) tidak memberikan penjelasan kenapa teori uppsala, real option dan jaringan industrial tidak dimasukkan dalam teori yang menjadi landasan untuk menjelaskan tentang pemilihan entry mode.

Lingkungan politik oleh De Villat et al. (2014) dipandang sebagai variabel penting dalam memoderasi keputusan memilih entry mode. De Villa et al. (2014) menyatakan bahwa perusahaan transnasional perlu menjadikan lingkungan politik sebagai bagian dari faktor yang harus dipertimbangkan tentang perannya dalam memoderasi proses pemilihan entry mode. Untuk itu, dia menyarankan dilakukannya analisis makro dan mikro terhadap lingkungan politik yang memiliki keterkaitan dengan entry mode ke pasar luar negeri. Dalam aspek makro, analisis yang dilakukan antara lain : perjanjian internasional di mana negera tujuan atau negara asal perusahaan transnasional terlibat di dalamnya, hubungan politik antara negara asal perusahaan transnasional dan negara tujuan, aturan hukum yang berlaku (the rule of law), dan sejarah politik di negara tujuan, Pada aspek mikro yang dianalisis adalah siapa saja kelompok kepentingan dan aktor politik yang kebijakannya dapat berdampak terhadap operasional perusahaan, asosiasi dagang dan asosiasi tenaga kerja yang mana yang dapat mendukung kebijakan perusahaan. Tetapi lingkungan politik dalam konstruk multilevel masih berupa tawaran konseptual belum diuji secara empiris perannya sebagai moderasi.

\section{Kerjasama Ventura Internasional}

Kesepakatan antara dua perusahaan atau lebih dimana perusahaan yang terlibat berbgai kepemilikan kendali terhadap perusahaan kerjasama ventura (joint venture) (Root, 1998), lebih efisien dibandingkan jika dikendalikan oleh satu pemilik (Hennart, 2000), dimana setiap mitra bisnis berkontribusi modal dalam bentuk uang, pabrik dan perlengkapan dan teknologi (Osland et al., 2001). Pemilihan strategi kerjasama ventura internasional juga didasari oleh manfaat kembalian investasi keuangan dalam jangka panjang yang jauh lebih baik dibandingkan model entri lainnya (Robson, Leonidou, \&

Katsikeas, 2002), bahkan kerjasama ventura internasional merupakan kendaraan 
penting bagi perusahaan multinasional dalam upaya berekspansi ke negara berkembang (Baird et al., 2017), yang keberadaannya telah mengubah lingkungan bisnis internasional dan menjadi salah satu entry mode populer di kalangan perusahaan multinasional, sekaligus menjadi strategi penting bagi perusahaan lokal yang bermitra dengan ventura internasional (Demirbag dan Mirza, 2000).

Tidak hanya itu, menurut Harrigan (1986) kerjasama ventura internasional juga mampu mengubahkan kompetensi yang kompleks yang dibutuhkan untuk membangun keunggulan bersaing, perannya semakin penting sebagai senjata strategis untuk bersaing dalam pasar dan teknologi yang dimasuki oleh suatu perusahaan.

Untuk menghimpun seluruh studi dalam bidang ini, Robson et al. (2002) telah mengembangkan satu framework integratif yang menghimpun seluruh dimensi yang berpengaruh terhadap kinerja ventura internasional. Dari 12 dimensi yang terdiri dari pengaruh internal dan eksternal, adapun variabel yang paling banyak digunakan adalah kecocokan antarpartner (interparter fit). Hal itu dibenarkan Thuy dan Quang (2005) dalam nada kritis dengan menyatakan bahwa penelitian yang dilakukan sebelumnya hanya menyoroti masalah hubungan antarpartner semata, tetapi pengetahuan tentang bagaimana faktor-faktor hubungan antarpartner yang mempengaruhi proses pertukaran diantara partner, pengkajiannya masih belum mendapatkan perhatian para peneliti.

Dalam pandangan pihak yang mendukung perspektif relasional antarpartner, argumentasi yang mereka kemukakan adalah pertukaran hubungan berfokus pada variabel yang dapat mempertahankan hubungan kemitraan seperti kepercayaan (trust), Komitment (commitment), kerjasama (cooperation), tugas yang saling kertegantungan (task interdependence), resolusi konflik (conflict resolution), komunikasi, peluang, dan kekuasaan (Thuy dan Quang, 2005), tetapi menurut Hersh dan Styles (2001) penerapannya dalam konteks IJV masih terbatas.

Sebagai contoh, Thuy dan Quang (2005) mengkaji tentang modal relasional (relational capital), dimana logika modal relational ini muncul sebagai akibat dari kritik terhadap teori biaya transaksi dan teori ketergantungan sumber daya. Kedua teori ini menurut Thuy dan Quang (2005) berfokus semata-mata pada oportunisme mitra (partner). Keduanya bersandar pada pendapat Gulati (1995) yang sebelumnya juga sudah lebih dulu menyoroti kegagalan teori tersebut dalam mengungkap elemen penting dari kemitraan, yaitu kepercayaan antara-perusahaan dan evolusi hubungan antar-mitra. Dalam hal variabel kepercayaan antar-perusahaan, diidentifikasi menjadi dua faktor: 1 . Kepercayaan berbasis pengetahuan, di mana perusahaan dapat saling percaya sebagai kibat interaksi dan saling memahami satu sama lain; dan 2. kepercayaan berbasis tekanan, dimana para mitra menjalin hubungannya didasari oleh sanksi keras bagi para pihak (mitra) yang tidak menaati kontrak yang telah disepakati. 


\section{Penelitian empiris}

\section{Variabel Dependen}

Variabel dependen yang paling umum digunakan adalah kinerja (Demirbag \& Mirza, 2000; Robson et al., 2002). Akan tetapi dalam hal operasionalisasi variabel kinerja terdapat perbedaan. Perbedaan ini juga diakui oleh Nippa \& Reuer (2019) yang secara kritis menggaris bawahi hal itu terjadi akibat kelemahan dalam penggunaan pendekatan biaya transaksi sebagai lensa teori dalam memahami perusahan ventura internasional.

Robson et al. (2002) menyebutkan bahwa jika dilihat dari variabel dependent, maka terdapat tiga variabel kerja sama ventura internasional yang umumnya diteliti yaitu : 1 . variabel keuangan, 2. stabilitas dan 3. multidimensi. Dari aspek keuangan (financial assesment) yang dinilai adalah profitabilitas dan pertumbuhan penjualan. Ada juga yang mengukur kinerja keungan secara persepsional yang dikaitkan dengan pencapaian sasaran ekonomi. Pengukuran stabilitas IJV sifatnya berdimensi tunggal, dalam melihat ketangguhan operasional suatu perusahaan ventura internasional yang diukur dari tinggkat pembubaran perusahaan yang muncul secara tidak terduga, atau permintaan negosiasi ulang modal yang muncul secara tiba-tiba. Kedua hal ini sering dikaitkan sebagai indikator dalam mengukur stabilitas IJV. Kemudian pendekatan multimensi, di mana penilaiannya dilakukan dengan menggabungkan seluruh dimensi mulai dari hasil pasar, keuangan, input, semangat kerja para karyawan, dan pemerolehan pengetahuan.pandangan multimendi adalah kebalikan dari dimensi tunggal, dengan kelebihan dari sudut objektivitas dalam melakukan penilaian dibandingkan variabel outcome (dependent variabel) yang berdimensi tunggal.

Pada sisi lainnya, Bener dan Glaister (2010) menggunakan kinerja perusahaan kerja sama ventura internasional sebagai variabel dependen dengan 15 indikator yang terdiri dari : (1) Kembalian investasi (2) Kembalian modal. (3) Pertumbuhan penjualan (4) Pangsa pasar (5) Pengendalian biaya (6) Produktivitas tenaga kerja (7) Manajemen kerjasama ventura (8) Transfer teknologi/pengetahuan yang efektif (9) Disain produk (10) Pengendalian mutu (11) Pemasaran (12) Pelayanan konsumen (13) Distribusi (14) Tampil di pasar lokal (15) mampu hadir di pasar lainnya. Ke-15 indikator itu dibagi dalam dua dimensi yaitu: profitabilitas dan efisiensi.

Dengan menggunakan pendekatan resource base, Ainuddin et al. (2007) menemukan bahwa atribut dari sumber daya itu mempengaruhi kinerja perusahan ventura internasional. Di mana perusahaan yang memiliki asset yang sifatnya bernilai (valueble), unik (rare), dan tidak dapat ditiru (inimitable) memiliki kencenderungan untuk menghasilkan kinerja yang baik. Temuan ini sekaligus memperkuat kontribusi resource based view dalam penelitian tentang kinerja perusahan kerjasama vetura internasional. 


\section{Independen Variabel}

Demirbag \& Mirza (2000) menguji pengaruh konflik antarmitra bisnis terhadap kinerja perusahaan ventura internasional. Beberapa indikator yang diukur antara lain pembagian keuntungan dengan perusahaan induk, upaya perusahaan induk dalam mengendalikan keputusan tertentu, jumlah laba yang ditahan, perluasan operasi atau mempertahankannya dalam ukuran tertentu, dan upaya mitra untuk mengubah persyaratan dalam kontrak ventura internasional. Variabel lainnya yang juga diteliti Demirbag \& Mirza (2000) adalah komitmen perusahaan induk, dan kepuasaan perusahaan induk.

Berdasarkan penelitian Robson et al.(2002), variabel independen yang dapat memprediksi kinerja dibagi dalam dua komponen besar yaitu faktor internal perusahaan ventura internasional dan faktor eksternal. Faktor internal memiliki variabel yang lebih dominan dibanding faktor eksternal. Faktor internal antara lain terhdiri dari karakteristik yang penting, Kesesuaian.kecocokan antarmitra, demografis ventura, elemen kontraktual, kendali dan penyeliaan, aspek hubungan proyek khusus, pembelajaran operasional, teknologi R\&D, pemasaran, sumber daya manusia. Sedangkan dari faktor eksternal ada dua variabel yaitu karakteristik industri dan lingkungan peraturan (Regulatory element).

Bener \& Glaister (2010) menguji lima faktor yang dipandang sebagai determinan terhadap kinerja perusahaan kerja sama ventura internasional. Kelima faktor yang diidentifikasinya itu adalah : 1. Kendali perusahaan induk; 2. Otonomi perusahaan kerjasama ventura; 3. Perbedaan budaya nasional diantara perusahaan kerja sama ventura internasional; 4 . Kepercayaan diantara mitra perusahaan kerja sama ventura internasional; dan 5. Perbedaan budaya antarperusahaan mitra kerja sama ventura internasional.

Dari hasil penelitian itu, Bener \& Glaister (2010) menemukan bahwa perbedaan budaya nasional diantara mitra perusahaan kerja sama ventura internasional berkorelasi negatif terhadap kinerja. Demikian halnya dengan perbedaan budaya perusahaan di antara perusahaan mitra kerja sama ventura internasional, sedangkan tiga faktor lainnya berdampak positif terhadap kinerja perusahaan baik pada sisi profitabiltias maupun efisiensi.

Studi yang cukup ekstensif juga dilakukan oleh Ren et al. (2009) yang menyimpulkan sebanyak 10 faktor pendorong kinerja yang terdiri dari: Komitmen, daya tawar, pengendalian, kepercayaan, keadilan, konflik, resolusi konflik, kerjasama, jarak budaya, dan kesamaan tujuan.

Selama empat puluh tahun lebih penelitian tentang strategi bisnis internasional, lebih spesifik dalam konteks kerja sama ventura internasional banyak terpusat pada 
persoalan perusahaan sebagai dependen variabel dan sejumlah prediktor seperti hubungan antarpartner, kendali yang dimiliki partner, perbedaan budaya nasional dan budaya perusahaan serta berbagai variabel lainnya. Namun arah penelitian ke depan sepertinya semakin menantang, terutama tantangan teoritis dan praksis. Apalagi jika ditempatkan pada konteks dunia yang sedang mengalami lonjakan kemajuan di bidang teknologi informasi dan komunikasi yang pada saat bersamaan juga tengah menghadapi pandemi wabah Covid-19.

Nippa \& Reuer (2019) merekomendasikan perlunya pengembangan lanjutan terkait dengan teori, metode, database, dan perangkat empiris guna mengatasi masalah kompleks yang dihadapi kerja sama ventura internasional yang baik. Dalam hal aliansi bisnis internasional ada satu probel perlu dicarikan solusi, terutama terkait dengan pengumpulan pengetahuan (knowledge acumulation) dan wawasan yang dapat digeneralisasi. Hal ini jika tidak diatas akan terus menimbulkan masalah dalam bidang kajian yang berbasis sumber daya (resource based). Untuk itu para peniliti dalam bidang bisnis internasional perlu memberikan penjelasan lebih lanjut tentang definisi dan operasionalisasi konstruk

Peluang penelitian lainnya yang masih terbuka untuk digarap adalah bagaimana pengalaman yang dikembangkan secara kolaboratif oleh mitra ventura internasional berpengaruh terhadap kinerja dalam mengakuisisi perusahaann lainya. Kemudian, pengembangan perusahaan ventura internasional dengan perusahaan ternama yang dapat memberikan petunjuk bahwa perusaha tersebut memiliki sumber daya yang besar dan praktik bisnis yang terbaik.

\section{Kesimpulan}

Kerjasama ventura internasional merupakan salah satu strategi internasional yang lazim digunakan oleh perusahaan multinasional ketika melakukan ekspansi ke berbagai negara yang menjadi destinasi investasi. Ventura internasional dipilih sebagai salah model entri untuk masuk ke pasar luar negeri dengan pertimbangan dari aspek hubungan antar mitra pembentuk ventura tersebut dan hubungan antara perusahaan induk dengan anak perusahaan di ventura di lakukan.

Setelah 48 tahun berjalan, penelitian dalam bidang model entri khususnya telah mengalami kemajuan yang cukup pesat. Para peneliti telah mengembangkan berbagai macam model dan kerangka kerja untuk memudahkan bagi para peneliti untuk melihat apa saja yang telah diteliti dan apa trend ke depan serta ruang-ruang yang masih tersedia untuk diteliti. 
Penelitian ini didominasi oleh para peneliti dari negara maju dan setting perusahaanperusahaan multinasional yang basisnya juga di negar-negara maju seperti Amerika dan Jepang. Hal ini dapat dimaklumi karena secara historis penelitian dengan topik strategi internasional khususnya kerjasama ventura internasional tidak dapat dipisahkan dari konteks kemunculan perusahaan multinasional di negara-negara maju yang kemudian berekspansi ke seluruh dunia.

Kemudian, penggunaan teori biaya transaksi telah mendapat kritikan karena lebih mengedepan pendekatan ekonomi, sebagai alternatif para peneliti mengajukan pendekatan integratif dengan menggunakan beragam teori dalam memahami ventura internasional. Bahkan ada juga peneliti yang mengembangkan teori berdasarkan budaya asli negaranya (misalnya Fung 2014) sebagai teori baru sebagai perspektif memahami ventura internasional.

Karena itu, penelitian strategi internasional dengan model entry kerja sama ventura internasional perlu diarahkan ke topik berikut ini:

1. Penelitian ke depan perlu dikaitkan dengan masalah-masalah kekinian terutama terkait dengan perkembangan teknologi informasi dan komunikasi dan berkembangnya industri 4.0 yang tentunya membuat berpengaruh terhadap aspek relasional, pengetahuan dan tentu kinerja perusahan ventura internasional.

2. Kemudian, faktor pandemi Covid-19 yang berimplikasi luas terhadap seluruh aspek perusahaan kerjasama ventura internasional. Beberapa permasalahan yang telah muncul adalah terbatasnya operasional bahkan penghentian operasional di daerah yang ditetapkan sebagai zona merah, keterbatasan akses pasar yang berakibat dan penurunan penjualan, pendapatan sehingga mengganggu proses operasional perusahaan. Karena itu dari aspek data tahan (resilience) perusahaan kerjasama ventura internasional juga perlu diteliti lebih lanjut terutama pasa saat pandemi dan pasca-pandemi Covid-19.

3. Pendalaman penelitian kerja sama ventura internasional pada sektor usaha kecil dan menengah (small and medium enterpise) yang selama ini dinilai masih kurang mendapatkan perhatian dari para peneliti, seperti dikemukakan oleh Lu dan Beamish (2006).

4. Terbuka peluang bagi peneliti untuk mengembangkan teori baru sebagai perspektif untuk memahami model entri dan kerjasama ventura internasional.

\section{Referensi}

Agarwal, S., and Ramaswami, S.N. (1992). Choice of Foreign Market Entry Mode: Impact of Ownership, Location and Internalization Factors. Journal of International Business Studies 23 (1):1-27. doi:10.1057/palgrave.jibs.8490257. 
Ahmad, S.Z., Kitchen, P.J. (2008). International expansion strategies of Malaysian construction firms: entry mode choice and motives for investment. Problems and Perspectives in Management, Volume 6, 3: 15-23.

Ainuddin, R. A., Beamish, P. W., Hulland, J. S., \& Rouse, M. J. (2007). Resource attributes and firm performance in international joint ventures. Journal of World Business, 42(1), 47-60. doi:10.1016/j.jwb.2006.11.001

Andersson, U., Johanson, J., \& Vahlne, J. E. (1997). Organic acquisitions in the internationalization process of the business firm. MIR: Management International Review, 67-84.

Baird, I.S., Lyles, M.A., Ji, S., \& Wharton, R. (1990) Joint Venture Success: A Sino-U.S. Perspective, International Studies of Management \& Organization, 20:1-2, 125134, DOI: $10.1080 / 00208825.1990 .11656529$

Bartlett, C.A. and S. Ghoshal (1989): Managing Across Borders: The Transnational Solution. Boston: Harvard Business School Press.

Bener, M., \& Glaister, K.W. (2010). Determinants of performance in international joint ventures, Journal of Strategy and Management, 3 (3), 188- 214.

Brooke, M.Z. and H.L. Remmers (1970): The Strategy of Multinational Enterprises: Organization and Finance. London: Longman.

Brouthers, K. D. (2013). A Retrospective On: Institutional, Cultural and Transaction Cost Influences on Entry Mode Choice and Performance. Journal of International Business Studies 44 (2):14-22. doi:10.1057/jibs.2012.23.

Brouthers, K.D., \& Hennart, J. (2007). Boundaries of the firm: Insights from entry mode research. Journal of Management, 33. 395-425.

Buckley, P. J., \& Casson, M. C. (1998). Analyzing foreign market entry strategies: Extending the internalization approach. Journal of International Business Studies, 29(3): 539-561.

Chang, S-J., \& Rosenzweig, P.M. (2001). The choice of entry mode in sequential foreign direct investment, Strategic Management Journal, Vol. 22(1), pp. 747-76.

Coviello, N. E. and Martin, K. A. M. (1999). Internationalization of service SMEs: An integrated perspective from the engineering consulting sector. Journal of International Marketing, 7(4), 42-66. 
De Villa, M. A., et al. (2014). Market entry modes in a multipolar world: Untangling the moderating effect of the political environment. International Business Review, http://dx.doi.org/10.1016/j.ibusrev.2014.10.001.

Sijabat, F. N. (2018). Entrepreneurial orientation, barriers, business networks, and internationalization readiness: A conceptual framework for the SMEs. International Journal of Academic Research in Accounting, Finance and Management Sciences, 8(3), 95-102.

Fung, A. (2014). International Business Strategies: A Review and Extension of Theories, Chinese Economy, 47(5-6), 116-130.

Geyskens, I., Steenkamp, J. B. E., \& Kumar, N. (2006). Make, buy, or ally: A transaction cost theory meta-analysis. Academy of Management Journal, 49(3), 519-543.

Gulati, R. (1995) Does familiarity breed trust? The implications of repeated ties for contractual choice in alliances, Academy of Management Journal, 38, 85-112.

Hans, M., \& Tallman, S. (1997). Control and Performance in International Joint Ventures. Organization Science: A Journal of the Institute of Management Sciences 8(3), 257-74. doi:10.1287/orsc.8.3.257.

Harrigan, K. R. (1986), Managing for Joint Venture Success, Lexington, MA: Lexington Books.

Hennart, J.F. (1988). A transaction costs theory of equity joint ventures. Strategic Management Journal, 9(4): 361-374.

Hennart, J. F. (2000). The transaction cost theory of the multinational enterprise. In C. Pitelis \& R. Sugden (Eds.), The nature of the transnational firm (2nd ed.): 81-116. London: Routledge.

Hennart, J.F. (2019). The transaction cost theory of equity joint ventures: Past, present and future. In F. Contractor \& J. Reuer (Eds.), Frontiers of alliance research. Cambridge, MA: Cambridge University Press.

Hermannsdottir, A. (2008). Theoretical underpinnings of the internationalization process. Institute of Business Research.

Hersch, L. \& Styles, C. (2001) International joint ventures: a political economy framework, Australasian Marketing Journal, 9(1), 20- 32.

Hill, C. W. L. (2007). International Business Competing in the Global Marketplace. Irwin, USA: McGraw Hill. 
Hill, C.W.L., \& Kim, W.C. (1988). Searching for dynamic theory of the multinational enterprise: a transaction cost model. Strategic Management Journal, Vol. 9, 93-1 04

Hitt, M. A., Li, D., \& Xu, K. (2016). International strategy: From local to global and beyond. Journal of World Business, 51(1), 58-73.

loanescu, D., Meyer, K.E., \& Estrin, S. (2004). Institutional Distance and International Business Strategies in Emerging Economies. William Davidson Institute Working Paper Number 728.

Johanson, J., \& Vahlne, J. E. (1977). The Internationalization process of the firm. Journal of International Business Studies, 8(1), 23-32.

Katavic, I. (n.d.) International business in changing global environment. Croatia: Polytechnic VERN.

Kumar, V., \& Subramanian, V. (1997). A contingency framework for the mode of entry decision. Journal of World Business, 32(1), 53-72. doi:10.1016/S10909516(97)90025-0

Lu, J.W., \& Beamish, P.W. (2006). Partnering strategies and performance of SMEs' international joint venture, Journal of Business Venturing, 21, 461-486. doi:10.1016/j.jbusvent.2005.02.002

Kim, W. C. \& Hwang, P.(1992). Global Strategy and Multinationals' Entry Mode Choice. Journal of International Business Studies, 29-53.

Kogut, B. (1998). Joint Ventures: Theoretical and Empirical Perspectives, Strategic Management Journal, 9, 319-332.

Kogut, B., \& Singh, H. (1988). The effect of national culture on the choice of entry mode. Journal of international business studies, 19(3), 411-432.

Lin, F. \& Ho, C. (2019). The knowledge of entry mode for small and mesium enterprise. Journal of Innovation and Knowledge, 4.32-37.

Muciimi, E. N., \& Ngumo, E. M. (2014). Implications of globalization for international business strategy: A multi-sectoral approach. International Journal of Science and Research, 3, 68-74.

Nowinski, W. \& Ralph, A. (2013). Drivers and strategies of international new ventures from a Central European transition economy. Journal for East European Management Studies 18,(2): 191-231. 
Osland, G.E.. Taylor, C.R., Zou, S. (2001). Selecting international mode of entry and expansion. Scholarship and Professional Work - Business.Paper 244. http://digitalcommons.butler.edu/cob papers/244.

Oviatt, B. M., \& McDougall, P. P. (1994). Toward a theory of international new ventures. Journal of International Business Studies, 25(1), 45-64.

Pan, Y., \& Tse, D. K. (1996). Cooperative strategies between foreign firms in an overseas country. Journal of International Business Studies, 27(5): 929-946.

Ren, H., Gray, B. \& Kim, K. (2009). Performance of International Joint Ventures: What Factors Really Make a Difference and How?. Journal of Management, 35: 805832. doi: $10.1177 / 0149206308331165$

Root F.R. (1998). Entry Strategies for International Markets. San Francisco: JosseyBass.

Root, F. R. (1994). Entry Strategies for International Markets. London, UK: Lexington Books.

Ruzzier, M., Hisrich, R. D., \& Antoncic, B. (2006). SME internationalization research: past, present, and future. Journal of Small Business and Enterprise Development, 13(4), 476-497.

Twarowska, K \& Kakol, M. (2013). International Business Strategy - Reasons And Forms Of Expansion Into Foreign Markets. Management, Knowledge Management, Knowledge Innovation \& Learning. Zadar. Croatia 19-21 Juni 2013.

Thuy, L.X., \& Quang, T. (2005). Relational Capital and Performance of International Joint Ventures in Vietnam. Asia Pacific Business Review, 11(3), 389-410.

Zhao, H., Luo, Y., \& Suh, T. (2004). Transaction cost determinants and ownershipbased entry mode choice: A meta-analytical review. Journal of International Business Studies, 35(6): 524-544.

* Artikel ini merupakan kertas kerja dan belum melalui proses peer review. Versi preprint ini disebarluaskan untuk tujuan mendapatkan masukan dari teman sejawat.

ferdi.ns@mhs.unsyiah.ac.id 